\title{
Neutrophil-to-lymphocyte ratio (NLR) and Platelets-to-lymphocyte (PLR) Ratio in Patients with Exacerbation of Bronchiectasis
}

\author{
NICOLETA STEFANIA MOTOC ${ }^{1}$, PAULA MARTINOVICI ${ }^{1}$, BEATRICE MAHLER BOCA ${ }^{2}$, IOAN SORIN TUDORACHE ${ }^{3}$, \\ TUDOR HARSOVESCU ${ }^{3}$, FLORENTINA LIGIA FURTUNESCU ${ }^{2}$, MILENA ADINA MAN ${ }^{1 *}$, CARMEN MONICA POP ${ }^{1}$ \\ ${ }^{1}$ Iuliu Haieganu University of Medicine and Pharmacy, 8 Victor Babes Str., 400000, Cluj Napoca, Romania \\ ${ }^{2}$ Carol Davila University of Medicine and Pharmacy, 8 Eroii Sanitari Blvd, 050474, Bucharest, Romania \\ ${ }^{3}$ Titu Maiorescu University, Faculty of Medicine, 22 Dambovnicului Str., 031593, Bucharest, Romania
}

\begin{abstract}
Neutrophil-to-lymphocyte ratio (NLR) and platelets-to-lymphocyte ratio(PLR) are novel inflammatorymarkers used in evaluation of systemic inflammation. The aim of this study was to evaluate the utility of NLR and PLR as inflammatory markers in patients with exacerbation of bronchiectasis. 100 patients with age between 23 and 88 years old with chest CT documentated bronchiectasis were included. Blood test were collected at admission in the hospital. There was a good correlation between classical markers such as CRP, ESR, white blood cells and NLR. PLR, however correlated only with ESR from the inflammatory markers and with the values og hemoglobin and hematocrit. We did not see higher values in patients with COPD and bronchiectasis when compared with patients with bronchiectasis alone, howevere patients with COPD GOLD stage 2 and bronchiectasis had higher values of NLR and PLR when compared with other stages. $N L R$, more than PLR can be safley used in evaluating inflammation in patients with exacerbation of bronchiectasis.
\end{abstract}

Keywords: Neutrophil-to-lymphocyte ratio (NLR), platelets-to-lymphocyte ratio(PLR), bronchiectasis, COPD

Bronchiectasis is a chronic inflammatory lung disease characterised by a clinical syndrome of cough, sputum production and bronchial infection, and radiological by abnormal and permanent dilatation of the bronchi [1]. The exacerbations of bronchiectasis represent deterioration in three or more of the key symptoms for more than 48 hours: cough sputum volume and/or sputum consistency [1, 2] and is associated with increased airways and systemic inflammation [3] and progressive lung damage [4-6]. Systemic inflammation induces an increase in neutrophils and platelets count accompanied by a decrease in lymphocyte count making their ratio (neutrophil-tolymphocyte ratio and platelets-to-lymphocyte ratio) a useful tool in the diagnosing chronic inflammatory diseases [5, 7]. In bronchiectasis the inflammation is primarily neutrophilic and it's due to persistent bacterial infection [8]. Excessive neutrophilic inflammation is linked to an increased frequency of exacerbations and rapid lung function decline through degradation of airway elastin, among other mechanisms [1-5]. NLR is assessing both the inflammatory status and cell-mediated immunity and it's increase in several systemic diseases, cancer, COPD, asthma, obstructive sleep apnea [5,7, 9-19]. Platelets have an important role in the immune system due to the surface receptors that enable them to recognize pathogens and immune complexes. Activated and adherent platelets release cytokines, including chemokines that stimulates inflammatory recruitment of immune cells $[20,21]$. The aim of this study is to evaluate the utility of NLR and PLR as inflammatory markers in patients with exacerbation of bronchiectasis compared with classical markers such as C-reactive protein, erytrocite sedimentation rate and white blood cells. As a second objective we wanted to see if in patients with COPD and bronchiectasis these markers are higher, considering that both conditions are associated systemic inflammatory status.

\section{Experimental part}

Materials and methods

This is a prospectively cross sectional study.

\section{Study population}

were enrolled all patients, over 18 years old with chest CT confirmed bronchiectasis consecutively hospitalized for a exacerbation of bronchiectasis in Leon Daniello Clinical Hospital of Pulmonology from Cluj Napoca, Romania in one year from January 2018 to December 2018. Exclusions criteria: were excluded hemodynamically instable patients, patients with severe comorbidities, patients with cystic fibrosis, pneumonia, lung cancer and interstitial lung disease. All patients signed an informed consent for participating in the study.

\section{Study protocol}

The study was approved by the Ethics Committee of University of Medicine and Pharmacy luliu Hatieganu, Cluj Napoca no 232/05.07.2019. Demographic data were collected directly from the patients. The exacerbation of bronchiectasis was defined according British Thoracic Society Bronchiectaisis Guideline [1]. Blood samples were taken from all the patients at admission in the hospital (before any intervention): complete blood cell counts and differential values were recorded. The NLR ratio was defined as the absolute count of neutrophils divided by the absolute count of lymphocytes. The PLR was defined as the absolute count of platelets divided by the absolute count of lymphocytes. CRP and ESR were determined.

\section{Statistics analysis}

Data was analyzed using SPSS v. 2 software for Windows. Values were presented as mean \pm standard deviation or, in the case of non-normally distributed data, as medians and $25^{\text {th }}$ and $75^{\text {th }}$ percentile. Independent-samples t-test, Mann-Whitney $U$ test and nonparametric tests were used for the comparison of continuous variables, with a significance level of 0.05 . Values are expressed as frequencies, percentages and mean \pm standard deviation. Spearman correlation analysis was done between NLR, PLR and other markers of inflammation. 


\section{Results and discussions}

100 patients with age between 23 and 88 years old (60.70 \pm 15 .1years old) with chest CT documentated bronchiectasis were included. Most patients were male (53 versus 47) and from urban aereas. Patients characteristics are shown in table 1.

Table 1

PATIENTS DEMOGRAPHIC CHARACTERISTICS

\begin{tabular}{|c|c|}
\hline Characteristics & Patients $(n=100)$ \\
\hline Age & $60.70 \pm 15.1$ \\
\hline $\begin{array}{cl}\text { Gender } & \\
\text { - } & \text { Male } \\
\text { - Female }\end{array}$ & $\begin{array}{l}53 \\
47\end{array}$ \\
\hline $\begin{array}{l}\text { Smoking status } \\
\text { - Current smoker } \\
\text { - Ex-smoker } \\
\text { - Never smoker }\end{array}$ & $\begin{array}{l}15 \\
34 \\
51\end{array}$ \\
\hline COPD & 37 \\
\hline Asthma & 21 \\
\hline Systemic diseases & 8 \\
\hline
\end{tabular}

The exacerbation of bronchiectasis was defined as deterioration in three or more of the key symptoms for more than 48 hours: cough sputum volume and/or sputum consistency. Patients laboratory tests are shown in table 2.

Purulent sputum was present in $54 \%$ of patients and we had a confirmed bacterial aetiology in $24.47 \%$ of cases. COPD was present in 36 patients.

There was a correlation between NLR and CRP, ESR and white blood cells (figure 1). This correlation did not exist betw een PLR and CRP or white blood cells (see figure 2). There is however a week correlation between PLR and ESR, haemoglobin and hematocrit.
Table 2

PATIENTS LABORATORY TESTS

\begin{tabular}{|c|c|}
\hline Test $(n=100$ patients) & Value $(\mu \pm D S)$ \\
\hline White blood cells (WBC) $\left({ }^{8} 10^{3} / \mu \mathrm{L}\right)$ & $8.23 \pm 3.04$ \\
\hline Eosinophils $\left(* 10^{2} / \mu \mathrm{L}\right)$ & $2.94 \pm 3.62$ \\
\hline Neutrophils $\left(* 10^{2} / \mu \mathrm{L}\right)$ & $5.57 \pm 2.82$ \\
\hline Lymphocytes $\left({ }^{*} 10^{2} / \mu \mathrm{L}\right)$ & $2.07 \pm 0.856$ \\
\hline Neutrophil-to-lymphocyte ratio(NLR) & $3.16 \pm 2.38$ \\
\hline Platelets $\left({ }^{*} 10^{3} / \mu \mathrm{L}\right)$ & $250.39 \pm 90.5$ \\
\hline Platelets-to-lymphocyte ratio (PLR) & $136.79 \pm 68.5$ \\
\hline C- reactive protein (mg/dl) & $21.83 \pm 42.7$ \\
\hline Erytocite sedimentation rate $(\mathrm{mm} / \mathrm{h})$ & $28.85 \pm 26.4$ \\
\hline Hemoglobin (g/dl) & $13.61 \pm 1.75$ \\
\hline Hematocrit (\%) & $40.94 \pm 4.91$ \\
\hline Saturation oxygen (satO2) (\%) & $94.88 \pm 4.06$ \\
\hline $\mathrm{paO} 2(\mathrm{mmHg})$ & $65.95 \pm 17.3$ \\
\hline $\mathrm{paCO} 2$ (mmHg) & $38.43 \pm 4.49$ \\
\hline
\end{tabular}

We did not notice higher values of NLR or PLR in patients with COPD and bronchiectasis, however an interesting observation was the higher values of both PLR and NLR in patients with COPD GOLD stage 2 compared with other stages (figure 3 and 4). There was no difference when looking at the distribution of the bronchiectasis.

In this study we evaluated the role of NLR and PLR as inflammatory markers in patients with exacerbation of bronchiectasis when compared with classical markers. We also wanted to see if in patients with bronchiectasis and COPD these markers have higher values. There was a good correlation between classical markers such as CRP,

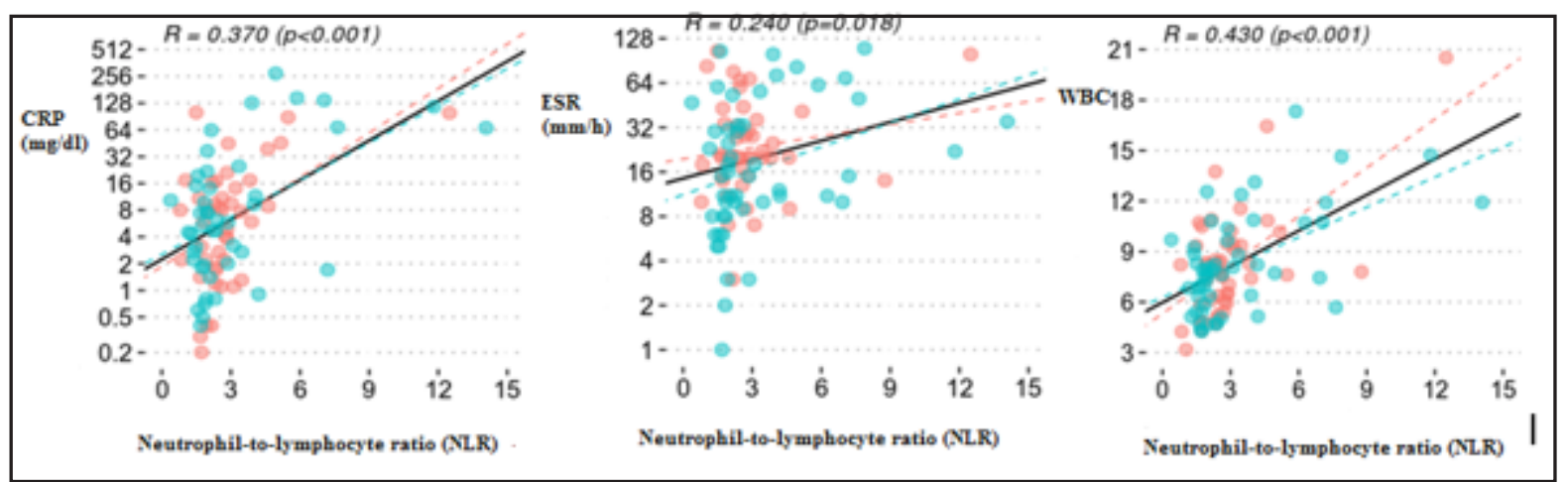

Fig. 1. Neutrophil-to-lymphocite ratio (NLR) correlations with CRP, ESR and white blood cells

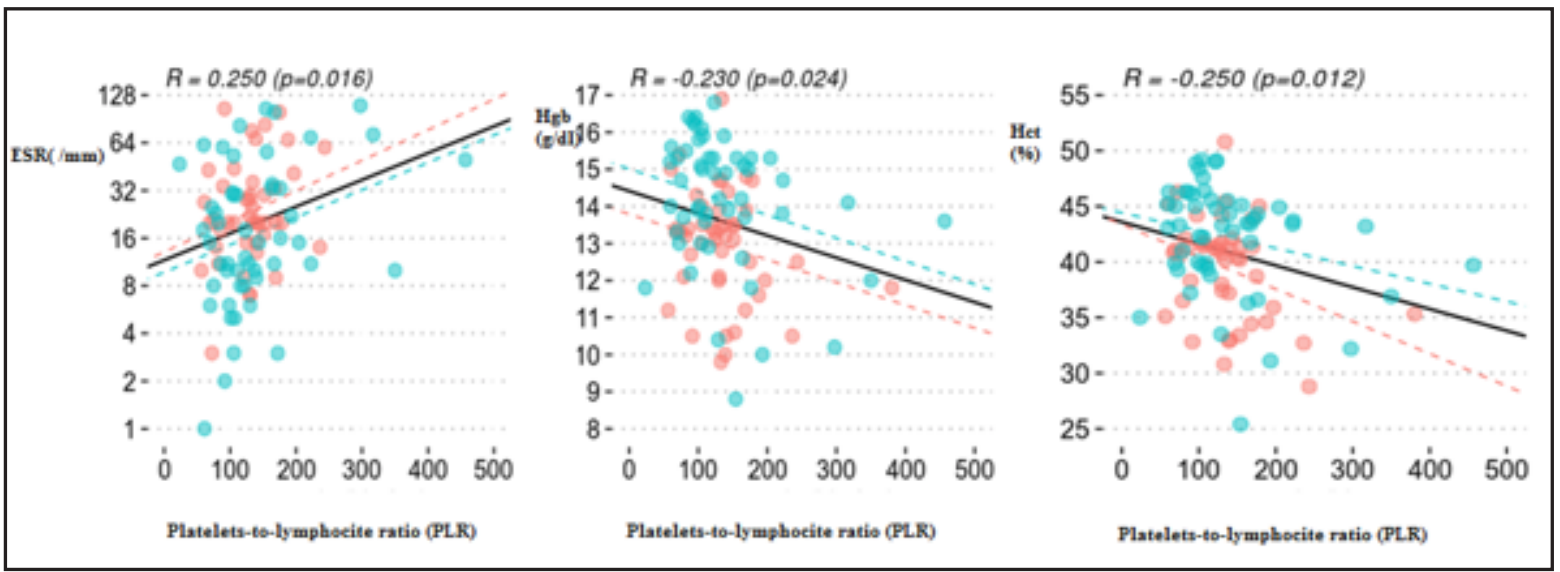

Fig. 2. Platelets-to-lymphocite ratio (PLR) correlations with ESR, hemoglobine and hematocrite 

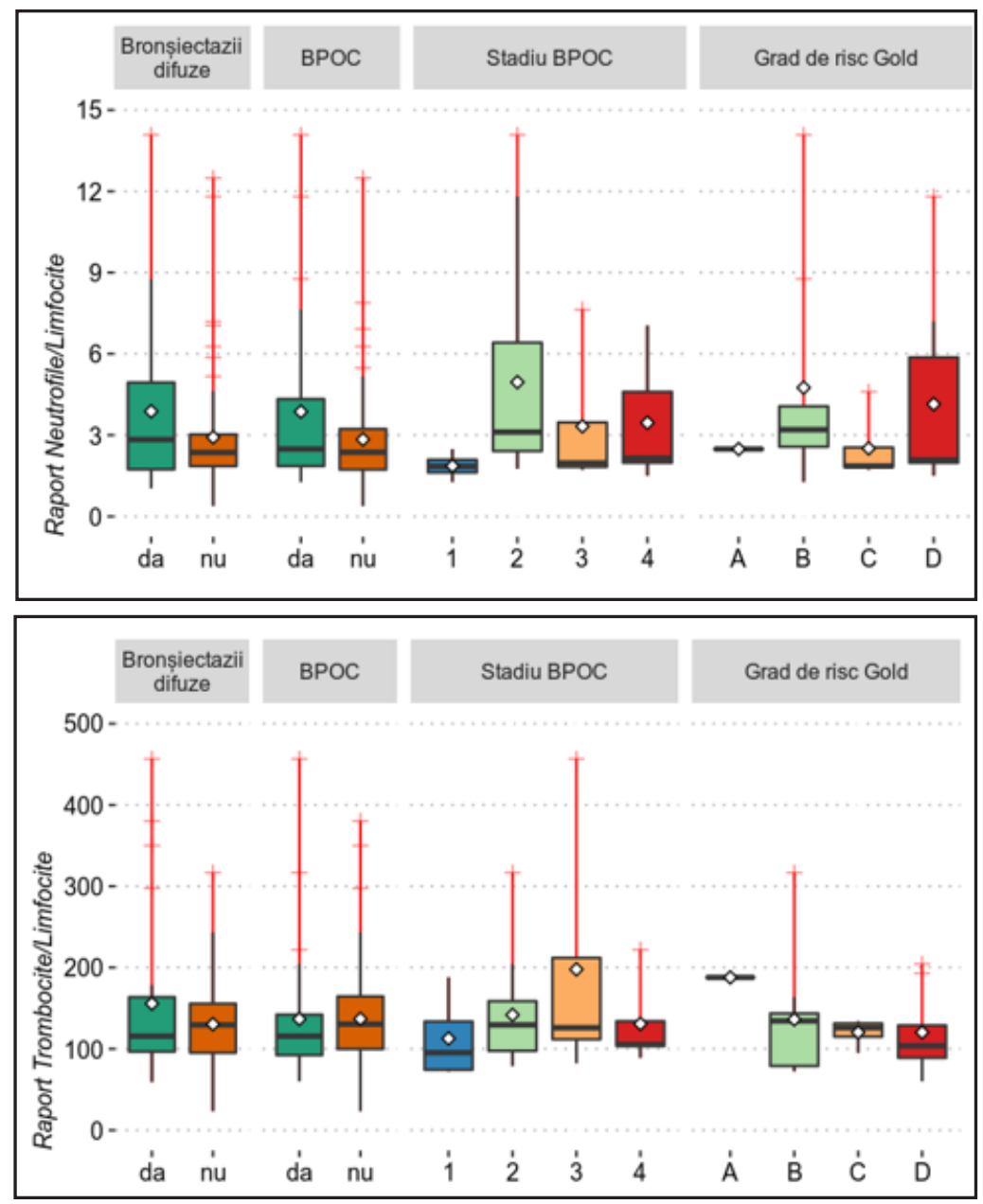

Fig. 3. Neutrophil-to-lymphocyte ratio in different subgroups
Fig. 4. Platelets to lymphocyte ratio in different subgroups
ESR, white blood cells and NLR. PLR, however correlated only with ESR from the inflammatory markers and with the values of hemoglobin and hematocrit. We did not see higher values in patients with COPD and bronchiectasis when compared with patients with bronchietasis alone, howevere patients with COPD GOLD stage 2 and bronchiectasis had higher values of NLR and PLR when compared with other stage of COPD. In recent years, multiple studies have been carried out to evaluate the utility of NLR and PLR as markers of systemic inflammation as they are more accessible and cheaper blood test. While NLR has been proven to be a reliable inflammatorymarker in solid tumors, COPD, sleep apnea and several of other disease the importance of PLR is still [17-23]. NLR is an independent prognostic factor in many solid tumors (eg, pulmonary, gastric). It is associated with disease severity, hospitalization, malnutrition, recurrence, and mortality in various chronic diseases such as cardiovascular or renal disease and has recently been studied as a predictive factor. of exacerbations and mortality in COPD. Thus, it was observed that NRL increases significantly in exacerbations compared to stable periods and that there are significant positive correlations between NLR, CRP and white blood cells. In the case of bronchiectasis, Nacaroglu et al [5] observed in a retrospective study that followed 50 pediatric patients that only absolute numbers of neutrophils and NLR can be used as biomarkers in acute exacerbations, the ratio does not have higher values. In our study COPD stage 2 patients had higher vales of both NLR and PLR when compared with other stages. It is well known that these patients represent a particular group as they have higher decline rate and higher risck to develop cancer. One possible explanation could be that in this particular subgroup of COPD patients the inflammation is more important.
The limitations of this study are: the small sample of patients and the absence of the control group.

\section{Conclusions}

While NLR correlates with classical inflammatory markers, the correlation is weak. The presence of COPD appears not to influence the inflammatory status in these patients. Further studies on subgroups are required.

\section{References}

1.HILL AT, SULLIVAN AL, CHALMERS JD et al. British Thoracic Society Guideline for bronchiectasis in adults. Thorax 2019; 74(Suppl 1):1-69. 2.POLVERINO E, GOEMINNE PC, MCDONNELL MJ , et al. European Respiratory Society guidelines for the management of adult bronchiectasis. Eur Respir J 2017; 50: 1700629

3.CHALMERS J D, SMITH MP, MCHUGH BJ, et al. Short- and long-term antibiotic treatment reduces airway and systemic inflammation in non-cystic fibrosis bronchiectasis. Am J Respir Crit Care Med 2012; 186: 657-665

4.SHEEHAN RE, WELLS AU, COPLEY S], et al. A comparison of serial computed tomography and functional change in bronchiectasis. Eur Respir J 2002; 20: 581-587.

5. NACAROGLU HT, ERDEM SB, KARAMAN S et al. Can mean platelet volume and neutrophil-to-lymphocyte ratio be biomarkers of acute exacerbation of bronchiectasis in children? Centr eur J immunol 2017; 42 (4): 358-362

6.NEMES, R.M., DUCEAC, L.D., VASINCU, E.G., AGOP, M., POSTOLACHE, $P$. On the implications of the biological systems fractal morphofunctional structure. University Politehnica of Bucharest Scientific Bulletin-Series A-Applied Mathematics and Physics 2015, 77(4):263272

7.YOON HY, KIM HN, LEE SH, KIM S], CHANG Y, RYU S, SHIN H, KIM HL, LEE JH. Association between Neutrophil-to-Lymphocyte Ratio and Gut Microbiota in a Large Population: a Retrospective CrossSectional Study. Sci Rep. 2018 Oct 30;8(1):16031. Thomsen M, 
Ingebrigtsen TS, Marott JL, Dahl M, Lange P, et al. (2013) Inflammatory biomarkers and exacerbations in chronic obstructive pulmonary disease. JAMA 309: 2353-2361.

8.GOLLI, A.L., NITU, M.F., BALASOIU, M., LUNGU, M.A., OLTEANU, M., NEMES, R.M., FORTOFOIU, M., RUSU, E., OLTEANU, M. Antibiotic resistance pattern of bacterial pathogens in elderl of bacterial pathogens in elderly patients admitted in the intensive care unit, Rev. Chim. (Bucharest), 69, no. 12, 2018, p. 3433-3438

9.LESAN, A., MAN, M.A., NEMES, R.M., HARSOVESCU, T., TUDORACHE, I.S., MAHLER-BOCA, B., POP, C.M., Serum interleukin 4 and 6 levels measured using the ELISA method in patients with acquired bronchiectasis compared to healthy subjects, Rev. Chim. (Bucharest), 70, no. 7, 2017, p. 2410-2414

10.IANOSI, E.S., POSTOLACHE, P., MACOVEI, L.A., SZATHMARY, M., SZASZ, S., NEMES, R.M., JIMBOREAN, G., Smoking cessation in COPD patients by a selective partial nicotinic agonist. Rev. Chim. (Bucharest), 69, no. 7, 2018, p. 1766-1769

11.IANOSI, E.S., DANTES, E., CSIPOR, A., SZATHMARY, M., SOCACI, A., RUSU, E., NEMES, R.M., Enhancing education for smoking preventing and smoking cessation in medical personnel: a measure for a better health. Rev Chim (Bucharest), 69 , no. 10, 2018, p. 2725-2727

12.MOCHIMARU T, FUKUNAGAK, KUWAE M, WATANABE R, OKUZUMI S, BABA R, KAMATANI T, TANOSAKI T, MATSUSAKA M, BETSUYAKU T. Neutrophil to lymphocyte ratio is a novel predictor of severe exacerbation in asthma patients. American Journal of Respiratory and Critical Care Medicine 2018, 197: A1406

13.CONSTANTIN B, POSTOLACHE P, CROITORU A, NEMES, RM. Occupational bronchial asthma - clinical and epidemiological aspects. J ournal Of Environmental Protection And Ecology 2015; 16(2): 517-520 14.AGUSTI A, NOGUERA A, SAULEDA J, et al. Systemic effects of chronic obstructive pulmonary disease. 2003 Feb;21(2):347-60. Review. EurRespir J 2003; 21:347-360.

15.ALEXESCU TG, MAIEREAN A, CIURMANEAN L, BUDIN C, DOGARU $G, T O D E A$ DA, Rehabilitation therapies in stable chronic obstructive pulmonary disease Balneo Research Journal 2019, 10(1):37-44
16.TRENCHEA, M., RASCU, A., OTELEA, M.R., BECHIR, E.S., DANTES E., TOFOLEAN, D.E., ION, I., ARGHIR, O.C., Increased Exhalated Carbon Monoxide, Smoking and Obstructive Sleep Apnea, Rev. Chim. (Bucharest), 70, no. 6, 2019, p. 2286-2289

17.JIMBOREAN, G., SZASZ, S., SZATHMARY, M., CSIPOR, A., ARGHIR, O.C., NEMES, R.M., POSTOLACHE, P., IANOSI, E.S., Association between Chronic Obstructive Pulmonary Disease and Sleep ApneaExperience of Pulmonology Clinic Tg Mures, Romania, Rev. Chim. (Bucharest), 69, no. 4, 2018, p. 1014-1017.

18.JIMBOREAN, G., SZASZ, S., SZATHMARY, M., . CSIPOR A, ARGHIR OC, NEMES RM, POSTOLACHE P, IANOSI E. Association between chronic pulmonary disease and sleep apnea - overlap syndromeexperience of Pulmonology Clinic Tg. Mures, Romania, Rev. Chim. (Bucharest), 69 no. 4, 2018, p. 1014-1017

19.POSTOLACHE P, NEMES RM, CROITORU A, CONSTANTIN B. The role of pulmonary rehabilitation in occupational COPD. Journal of Environmental Protection and Ecology 2015, 16(2):521-527.

20.KAUSHANSKY K (2005) The molecular mechanisms that control thrombopoiesis. J Clin Invest 115: 3339-3347

21.GABRIELSKA A, LUKASIK ZM, MAKOWSKA J et al. Obstructive sleep apnea: from intermittent hypoxia to cardiovascular complication via blood platelets. Front. Neurol. 2018; 9:635

22.PALIOGIANNIS P, ALESSANDRO G. FOIS, SS et al. Neutrophil to lymphocyte ratio and clinical outcomes in COPD: recent evidence and future perspectives EurRespir Rev 2018; 27: 170113

23.TAYLAN M, DEMIR M, KAYA H, et al. Alterations of the neutrophillymphocyte ratio during the period of stable and acute exacerbation of chronic obstructive pulmonary disease patients. ClinRespir] 2017; 11: 311-317.

24.LEE SJ, LEE HR, LEE TW, et al. Usefulness of neutrophil to lymphocyte ratio in patients with chronic obstructive pulmonary disease: a prospective observational study. Korean J Intern Med 2016; 31: 891-898.

25.*** Global Initiative for Chronic Obstructive Lung Disease, 2018. Weblog. Available from:https://goldcopd.org/[Accesed on : $2^{\text {nd }}$ October 2018]

$\overline{\text { Manuscript received: } 14.05 .2018}$ 